Anna L. Krasnova

Moscow Theological Academy of the Russian Orthodox Church, Postgraduate student of the Theory and History of Church Art Departmen

\title{
EARLY ATHOS AND SINAI ENGRAVINGS AND THEIR ICONOGRAPHIC SOURCES: ICONS, PROSKYNETARIONS, GEOGRAPHICAL MAPS
}

Summary: A comprehensive study and understanding of Greek religious engravings require identifying iconographic sources and understanding the masters' choice of certain works. Which in turn reveals the purpose and history of the existence of Greek engravings. Icons were often the subjects of religious engravings. Therefore, such engravings have a second name, "icons on paper"; along with them, views of monasteries and holy places were depicted. There is a separate genre in books, icons, religious paintings ${ }^{1}$, cartography, and that is images with views of the Holy Places: Jerusalem, Sinai and others. In an icon, this manifested itself in the form of large panramic polyp view of centuries. This genre of proskynetarions appeared as a synthesis of geographical maps representing holy cities and areas (such maps have become widespread since the $16^{\text {th }}$ century) and travel sketches of travellers - naturalist scientists, researchers of antiquity and,

Today it is so rare that Greek religious engravings, a phenomenon of the mass Christian culture of the $19^{\text {th }}$ century, still keep the secret of their or igin. It is difficult to give a definite answer to the question of the purpose of such works. On the one hand, Greek religious engravings were used everywhere on Athos as icons - prayer images. And on the other hand, there are references to the fact that engravings were distributed to pilgrims for the rev-

1. As an example - Frederick III in the Holy Land commissioned by Frederick III, Elector of Saxony in 1503 of course, pilgrims. It is essential to understand what place Greek Orthodox engravings occupy among all these monuments. This study helps to answer this question partially. Several monuments were identified from catalogues using the method of bibliographic heuristics: icons, early Greek engravings, works by icon painters, early geographical maps, illustrations of proskynetarions, picturesque panoramas of the Holy Land, which made up material for an overview iconographic analysis. It made it possible to prove that the monks ordering prints in European cities and producing Greek religious engravings on their own used absolutely all possible richness of subjects, art monuments different in genre and execution techniques. They created a new phenomenon - the engraving of the Greek world, which organically fitted into the context of the existing culture.

Keywords: Greek engraving, iconographic sources, proskynetarion, post-Byzantine icon, views of the Sinai monastery, pilgrimage.

erent memory of the pilgrimage, often in exchange for alms. The variability of the purpose in the use tion of subjects. A large number of composition are presented directly by icons - images of Christ the Mother of God, saints and holidays. The landscape genre - architectural views of Greek monasteries, is the second large group. A special group includes printed images of antimins on fabric, which were created based on the drawn ones. Patriarchs' permits, the so-called indulgences, are presented as a separate genre.
The plots of the earliest Greek engravings can eveal the mystery of their origin. Among those that have come down to our time, the most ancient Greek engravings are images of saints of the $16^{\text {th }}-17^{\text {th }}$ centuries. We know of several woodcuts from the publication Khilandarska Graphics of Serbian researcher D.Davidov. This is Deisis - Christ is depicted sitting on the throne with the forthcoming Mother of God and Forerunner The Crucifixion with the Forthcoming, a graphic icon in a frame with wide ornamentation from the early $16^{\text {th }}$ century from the Khilanda monastery on Mount Athos, is very beautiful. In the same style, a four-part icon with images of the Mother of God, the Archangel Michael, and martyrs Nedelya (Sunday) and Petka (Friday) [5, pp.15-17] has been preserved. In Venice at the beginning of the $16^{\text {th }}$ century, Serbian publishers, the Vukovicis, decorated printed Orthodox books with xylography, created in a similar style, close to Byzantine art [9]

This group of monuments includes a $17^{\text {th }}$-century engraving, John the Baptist, Angel of the Desert, from the Dionysios Monastery [6]. As for the origin of this engraving, stylistically, it is very close to the copies of the Cretan school iconographers, which we know about from the personal collection of Greek art critic Andreos Xyngopoulos. They are now kept in the Benaki Museum (Athens) [14] These sketches were published by Greek art critic Maria Vassilaki in the catalogue Working Drawings of Icon Painters after the Fall of Constantinople from the Collection of Andreos Xyngopoulos of the Benaki Museum in 2015. The icons presented here, similar in style and identical in time of creation to the engraving John the Baptist, Angel of the Desert, are shown in the catalogue under № 75, 81. Describing these drawings, Vassilaki notes that such iconography is found on the $15^{\text {th }}$-century icon owned by the London Society of Antiquaries (Byzantium 1994, No. 231, M.Vassilaki), as well as on the icon from the Church of St. Matthew of the Sinaites in Heraklion, Crete, attributed to Michael Damaskinos (second half of the $16^{\text {th }}$ century). Also, these works are very similar in composition and drawing style of the icons by a Cretan icon painter of the $17^{\text {th }}$ century, Theodore Pulakis, who probably used them in his work. This is how they were used: the artists applied tracing paper to make copies of ancient icons of the $15^{\text {th }}-17^{\text {th }}$ centuries and then transferred the drawing onto a clean gesso to paint a new icon. It is possible that these examples and copies were used to create engravings. Like icon painters' tracing cop-

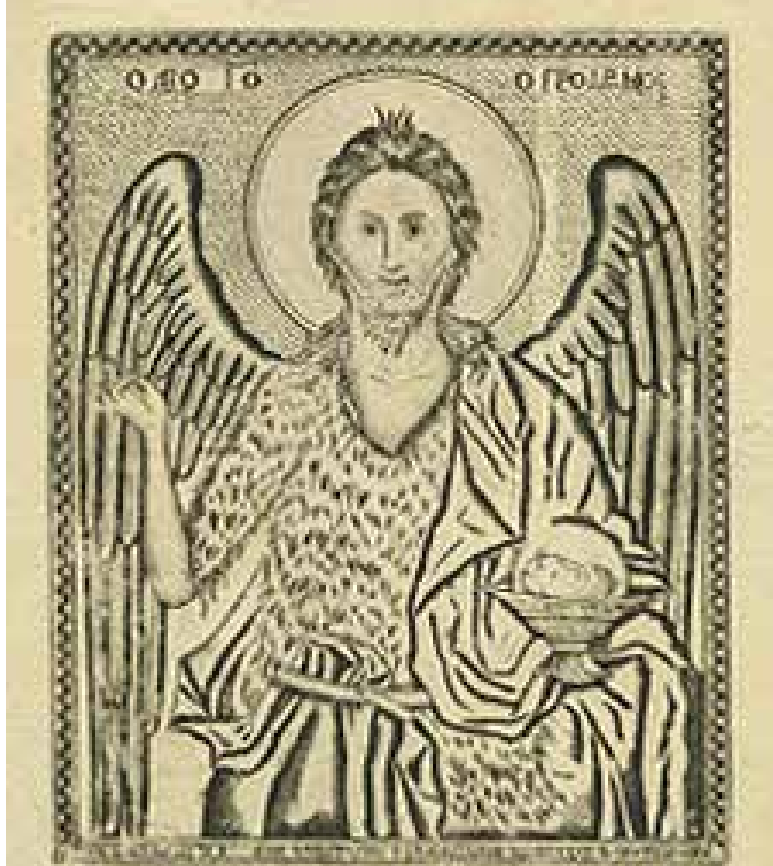
John the Baptist - Angel of the Desert. Athos. Mid-1 1 gh $^{\text {ch }}$ century Unknown engraver. Cutter, etching (dotted line). $31.9 \times 25.7(44$ $x 33.4)$ cm. From the
Theological Academy

ies, early woodcuts were made linearly, suggesting that graphic artists could have used such sketches by icon painters to create engravings. In any case, the prototypes for creating early Orthodox woodcuts were either icons themselves or icon-painting examples for painting icons.

These images are direct followers of Byzantine icons and miniatures. In fact, this is Serbian engraving, a single cultural phenomenon with the Greek graphics of that period. The authors of these works drew their inspiration from the continuation of the Byzantine artistic tradition.

Natella Topuria suggests that the Sinai sheets were printed even earlier - in the $15^{\text {th }}$ century: however, they have not survived [13].

One of the earliest known Sinai engravings, The Burning Bush, a View of the Monastery of St. Cathe rine of Sinai, by master Cornelius is of interest. The researchers date it to 1665 [8]. This composition was very popular; thus, several freely interpreted copies were made of it. One such unique sheet of the late $17^{\text {th }}$ and early $18^{\text {th }}$ century is kept in the collection of the Museum of the Moscow Theological Academy (Papast. No. 394) [7]. The engraving is interesting not only because it is one of the earliest known Greek engravings and the oldest among Russian collections but also because of its composition. Not only the traditional icon-painting images of the Burning Bush, the Prophet Moses and St. Catherin 


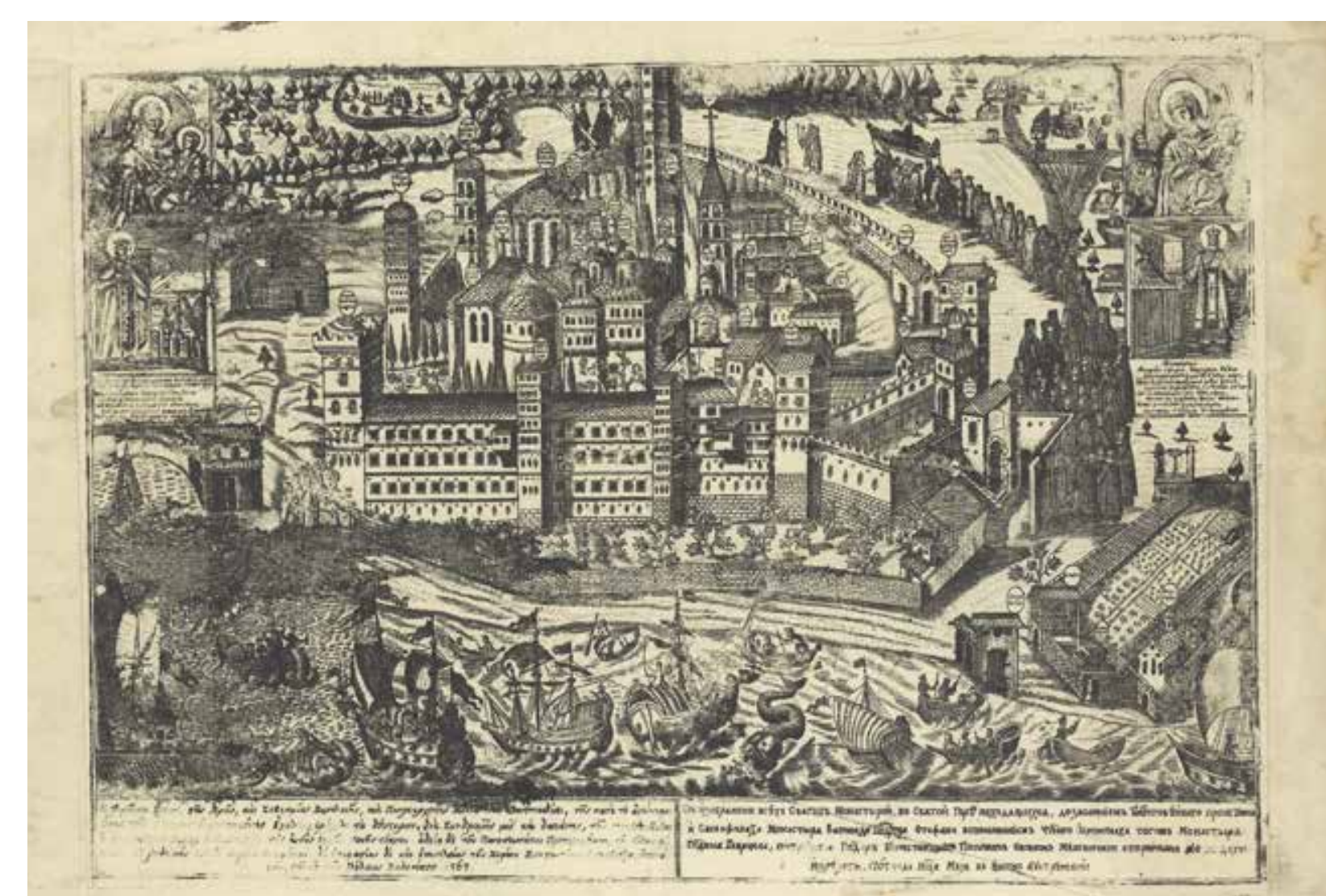

"View of the Vatoped monastery". 1767. Vienna. Mid-19th century reprint. Unknown engraver
$45.5 \times 63.2(52.4 \times 75.4) \mathrm{cm}$. From the collection of the Museum of the Moscow Theological Academy.

are presented there, but also the surrounding area is illustrated interestingly. The artist created a narrative image of the Holy Land - the Monastery of St. Catherine. The whole illustrated action is against the background of an ascetic mountain landscape, and a small monastery is in the foreground. That is, this icon represents a composition in which the landscape begins to play an important role.

Another early Sinai woodcut, The General view of the Sinai Monastery, was made by master Akaki in $1665[8$, p.341]. The composition is stylistically painted with a line, and the mountain landscape looks like a map. Here, several techniques of spatial constructions are used simultaneously: from one angle, the viewer perceives two-dimensional and conventionally depicted flat mountains, and from another angle - the land of Egypt. The building of the monastery is shown in axonometric projection from above.

In Lvov, master Nikodim Zubritskiy made the nex in time engravings with a view of Sinai. Starting from 1688 to the end of the $17^{\text {th }}$ century, he had created four similar engravings with minor differences (Papast. No. 380-383). The first two sheets are with slight differences. Papast. No. 380 has a decorative frame and is in Sinai. Papast. No. 381 is kept in the National Library in Paris. A deeper space is depicted in these works; the foreground and background are clearly visible. In terms of spatial constructions, thes sheets are closer to the specific European engraving. Master Nikodim Zubritskiy began to use texture and tone more actively in engravings, creating modelling of forms in landscape elements. Researchers studying Zubritskiy's work have a common opinion that all these compositions were made on the basis of an engraving by Giovanni Batista Fontana (1524-1587) created in Venice in 1569 (now kept in the Uffizi Gallery) [15]. Researchers D.Papastratu [8, p. 338.] and V.Delyuga [4, p. 383.] cite it as a prototype of the $\mathrm{Si}-$ nai views. El Greco's Modena Triptych, on the back of which the master depicted a Sinai landscape of identical composition, was created at the same time. Several such pictorial compositions, triptychs, the folds of which represented the Sinai landscape, were created at the end of the $16^{\text {th }}$ century. El Greco's Landscape of Sinai from the Historical Museum in Crete, View of Mount Sinai by an unknown icon-painter from the collection of the Vatican, a triptych fold from the Blunt collection in London [15] are also known. Since all these compositions were created at about the same time, 1560-1590, most likely there was some source that served as a model for them. Perhaps this was an icon from the St. Catherine's Monastery collection which researcher R.Todorova cites in one of her articles and dates it to the $13^{\text {th }}$ century [12]. In the $17^{\text {th }}$ century, this iconographic type served as an example for creating Sinai woodcuts and then engravings on copper with a view of Sinai.

The very first engraving with a view of Sinai, which preceded all those described above, was created in Paris from a sketch by the French naturalist and professor, Pierre Belon (1517-1564), who visited Turkey, Greece, Athos, Palestine, Egypt and the Sina Peninsula. The engraving was published in an illustrated description of this trip in 1553 [10]. The two peaks of Mount Sinai are depicted as a single rocky mass with a slight hint of the volume of the stone blocks of rocks; the monastery of St. Catherine is in the foreground. The image of Mount Athos is also known from this edition; it is made in more detail and more realistically.

It is an ancient tradition to describe pilgrimages to the Holy Land and accompany such travel descriptions with illustrations. From the $15^{\text {th }}$ century, the culture of pilgrimage had become more popular. Many wanted to capture somehow the memories of their stay in the Holy Land and share their impressions with those who had not yet made the pilgrimage. The publication of Travels to the Holy Land in 1486 illustrated with woodcuts created by artist Erhard Reuwich, who was a direct participant in this journey, resulted from the expedition to the holy places undertaken by Bernhard von Breydenbach, Dean of Mainz Cathedral. The artist depicted the land of Egypt and the monastery of St. Catherine [2]. The image is more like a map than a landscape. For sure, the task was not to get to the Holy Land using this map; however, it colourfully and conventionally conveyed the location of the main sites relative to each other and presented their appearance in a naturalistic way. At this time, in 1493, the Nuremberg Chronicle was created by scientist Hartmann Schedel. In the book, there are 1809 illustrations, among which The View of Constantinople is compositionally very similar to Athos engravings with views of monasteries by the sea [1]
It is worth noting that the Sinai Monastery was the first to publish such panoramic images with view of its monastery. Most of the engravings were ordered by merchant Hatzikiriyakis from Nikodim Zubritskiy and Dionisy Sinkevich. The engravings were distributed in large editions (up to 1000 sheets) to pilgrims. Often monks of individual monasteries travelled throughout Europe and the Russian Empire and handed out engravings with views of monasteries and shrines in exchange for donations, which was especially necessary during the period of occupation by the Ottoman Empire, which imposed tax obligation on the monasteries.

Noting the benefits and effectiveness of distributing such engravings in popularising information about monasteries and for raising funds for their existence, Athos monasteries, which were not so popular and did not possess such authority as the Divine Mount Sinai, took up this idea and began to actively order engravings depicting the monastery and its shrines, accompanied by short descriptions of historical and miraculous events [3], in Europe, mainly in Venice. Often, the masters who carried out such orders specialised in the production of geographical maps, which, in the $17^{\text {th }}-18^{\text {th }}$ centuries, were made using the technique of etching and engraving and were distinguished by their decorativeness and beauty of execution; the engraved map of the British Isles of 1558 [11] can be mentioned as one of the earliest. They were often decorated with drawing of ships and mythical fish, which can be found in almost all graphic views of Athos monasteries, starting with the Sinai ones. In part, such images were copied not only for aesthetic reasons, but they also reflected a painful historical situation for monasteries - pirate attacks on them. In the hope of stealing material values, the monasteries were terrorised by Turks, Venetians, Spaniards and pirates of other origins. Such robberies had been committed since the $13^{\text {th }}$ century, and with the strengthening of Turkish power, they had progressed [16]. Thus, engraving illustrating the fabulous space of holy places were often very truthful in their narrative.
REFERENCES

1. Ayse Yetiskin Kubilay Maps of istanbul Haritaları 1422 1922 İstanbul: Denizler Kitabevi, 2010 .
Breidenbach, Bernhard von Peregrinatio in Terram Sanc2. Breidenbach, Bernhard von Peregrinatio in Terram Sanc-
$\operatorname{tam}=$ Die heyligen reyssen gen Jherusalem. Mainz: Er- hard Reuwich [cum typis Petri Schöfferi], 21.VI. 1486 illustration Sinai by E.Roivih URL: https://www.wdl.org/ ru/item/18197/view/1/264/ (accessed 22.04.2021). 
3. Della Dora V. 1947. "Turning Holy Mountains into Ladders to Heaven: Overlapping Topographies and Poetics of Space in Poste-byzantine Sacred Engravings of Mount Sinai and Mount Athos", Approaching the Holy Mountain: art and liturgy at St Catherine's Monastery in the Sinai . I. Series II. Gerstel, Sharon E. J. III Nelson, Robert S., p. 506.

4. Deluga, W. 1997. Views of the Sinai from Leopolis. Shoter Notise. Print Quarterinq, XIV, 4, p.383.

Dinko, D. 1990. Hilandarska graphics. Beograd «Prosveta"

6. Kampanis. M. "The Printmaking. Tradition on Moun Athos", The Orthodox Arts Journal URL: https//orthodoxartsjournalorg/the printmaking-tradition-onmount-athos/ (accessed 20.04.2021).

7. Krasnova A 2021. "Engraving "The Burning Bush, View of the Monastery of St Catherine, Sini" a men"TSAK"', Theological Bulletin, no. 2, vol. 41

8. Papastratos, D. 1990. Paper Icons. Greek Orthodox RePagious Engrovings 1665-1899: (Vols. 1-2), vol. 2. PP. 360-361, Athens

9. Petkovic, S. 1995.

Petkovic, S. 1995. "Greek Influence on Illustration in Serbian Books Printed in Venice in the $16^{\text {th }}$ Century Aplopertes $x$ a kroypayor", Metaßuzautwa

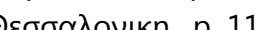

. Pierre Belon URL: https://ru.wikipedia.org/wiki/Pierre

11. Schüler, C.J. 2010. Die Geschichte der Kartographie. Editions place des victoires.

12. Todorova, R. 2015. "Icons as Maps: Cartographic icons in Orthodox art", Eikón Imago 7 (2015/1)

13. Topuriya, N.A., Hromov O.R. 1996. "Opisanie lerusalima" Simeona Simonovicha i Hristofora Zhefarovicha v russkih lubochnyih izdaniyah. Issledovaniyaya i svodnyiy katalog knig, hranyaschihsya v moskovskih sobraniya ["Description of Jerusalem" by Simeon Simonovich and Christopher Zhefarovich in Russian popular prints. Research and consolidated catalogue of books stored in search and consolid Moscow p. 22 . Vassitki M. 2015. Wor

pings of Icon Painters after the Fall of Constantinople. The Andreas Xyngopoulos portfolio at The Benaki Museum

15. Vassilaki, M. Three Questions of the Modena Triptych URL: http://archive.eclass.uth.gr/eclass/modules/document/file.php/SEAD216/M.\%20Vassilaki\%2C\%20

Three\%20Questions\%20on\%20the\% 20Modena\% 20Triptych.pdf (accessed 22.04.2021)

16. Zoitakis, A. Encyclopedia of Athos / Turkish Dominion URL: https://athos.guide/encyclopedia/ mistor Dominance (accessed 22.04.2021)

Анна Леонидовна Краснова Московская духовная академия Русской Православной Церкви аспирант кафедры Теории и истории церковного искусства

e-mail: anna.my.cloud@icloud.com Россия, Сергиев Посав

DOI: 10.36340/2071-6818-2021-17-3-24-32

ORCID 0000-0002-1393-0245

\section{РАННЯЯ АФОНСКАЯ И СИНАЙСКАЯ ГРАВЮРА \\ И ИХ ИКОНОГРАФИЧЕСКИЕ ИСТОЧНИКИ: ИКОНА, ПРОСКИНИТАРИИ, ГЕОГРАФИЧЕСКИЕ КАРТЫ}

Аннотация: Вопрос комплексного изучения и понимания греческой религиозной гравюры требует выявления иконографических источников и осмысления выбора мастерами тех или иных образцов, что в свою очередь приоткрывает нам назначение и историю бытования гре ческих гравюр Часто сюжетами религиозных гравюр выступали иконы, поэтому такие гравюры имеют второе название «иконы на бумаге», при этом наряду с ними изображались виды монастырей и святых мест. Существует отдельный жанр в книге, иконе, религиозной картине ${ }^{1}$, картографии - изображения с видами Святых Мест Иерусалима, Синая и прочих. В иконе это проявилось особенно в XVIII-XIX вв. в виде больших панорамных полиптихов, напоминающих «иконостас с видом святых мест». Это жанр проскинитариев возник как синтез географических карт, репрезентующих святые города и местности, такие карты получили широкое распространение c XVI в., и путевых зарисовок путешественников - учёных-натуралистов, исследователей старины и, безусловно, паломников Важно понять, какое

Столь редкое явление сегодня - феномен мас овой христианской культуры XIX в. - греческая религиозная гравюра по-прежнему хранит тайну своего происхождения. Сложно определённо ответить на вопрос о назначении подобных про1. Как пример «Фридрих III на Святой Земле», созданной по
заказу Фридриха III курфюрста из Витенберга в 1503 г. место среди всех этих памятников занимает греческая православная гравюра. Данное исследование помогает ответить отчасти на этот вопрос. Методом библиографической эвристики по каталогам был выявлен ряд памятников: иконы, ранние греческие гравюры, образцы иконописцев, ранние географические карты, иллюстрации проскинитариев, живописные панорамы Святой Земли, - составившие материал для проведения обзорного иконографического анализа. Данный анализ позволил убедиться в том, что монахи, заказывавшие эстампы в европейских городах и изготавливавшие греческие религиозные гравюры самостоятельно, использовали абсолютно всё возможное богатство сюжетных образцов и памятников искусства, разных по жанру и технике исполнения. Таким образом сложилось новое явление - гравюра греческого мира, органично вписавшаяса в контекст существовавшей культурь.

Ключевые слова: греческая гравюра, иконографические источники, проскинитарий, пост-византийская икона, виды Синайского монастыря, паломничество

изведений. С одной стороны, греческие религиозные гравюры использовались повсеместно на Афоне как полноценные иконы в роли молельных образов. И в то же время, с другой сторонь есть упоминания о том, что гравюры раздавалис паломникам на благоговейную память о палом ничестве, часто в обмен на милостыню. Вариативность назначения в использовании греческих 
гравюр обусловлена и составом сюжетов. Большое количество композиций представлено непосредственно иконами - образами Христа, Богоматери святых и праздников. Вторая большая группа представлена пейзажным жанром - архитектурными видами греческих монастырей. В особую группу можно отнести печатные изображения антиминсов на ткани, которые создавались по образцу рисованных. Отдельным жанровым направлением представлены разрешительные грамоты патриархов, так называемые индульгенции.

Сюжеты самых ранних греческих гравюр могут приоткрыть тайну своего происхождения. Из дошедших до нашего времени самыми древними XVI-XVII вв. Нам известны несколько ксилографий из публикации сербского исследователя Д. Давидова «Хиландарска графика», а именно «Деисус» - Христос изображён восседающим на престоле с предстоящими Богоматерью и Предтечею. Там же опубликована графическая икона «Распятие с предстоящими» в раме с широким орнаментом начала XVI века из афонского монастыря Хиландар. В единой с ними стилистике сохранилась четырёхчастная икона с изображениями Богоматери архангела Михаила и мучениц Недели (Воскресенье) и Петки (Пятница) [5, с. 15-17]. В начале XVI в. в Венеции сербские издатели Вуковичи оформля ли печатные православные книги ксилографиями создававшимися в подобной стилистике, близкой к византийскому искусству [9].

К этой группе памятников можно отнести гравюру XVII в. «Иоанн Предтеча Ангел Пустыни» из монастыря Дионисиат [6]. Что касается происхождения этой гравюры, стилистически она очень близка переводам иконописцев критской школы, которые нам известны из личной коллекции греческого искусствоведа Андреоса Ксингопулоса, хранящейся сейчас в музее Бенаки (Афины) [14]. Эти эскизы были опубликованы греческим искусствоведом Марией Вассилаки в 2015 г. в каталоге «Рабочие рисунки иконописцев после падения Константинополя из коллекции Андреоса Ксингопулоса музея Бенаки». Приведённые здесь иконные образць близкие по стилистике и идентичные по времени создания к гравюре «Иоанн Предтеча, Ангел Пустыни» представлены в каталоге под № 75, 81 Описывая эти рисунки М. Вассилаки отмечает, что подобная иконография встречается на иконе $\mathrm{XV}$ в. находящейся во владении Лондонского общества антикваров (Византия 1994, № 231, М. Вассилаки), а также на иконе из церкви Святого Матфея Синаитского в Ираклионе, Крит, приписываемой Ми хаилу Дамаскину (2-я половина XVI в.). Также эти образцы очень похожи по композиции и рисунку на иконы критского иконописца XVII в. Феодора Пулакиса, который, вероятно, пользовался ими в своей работе.

Также можно описать технологию их использования: художники снимали кальки с древних икон XV-XVII вв., а далее с них переносили рисунок на чистый левкас для написания новой иконы. Вполне возможно, что эти образцы и сколки использовались для создания гравюр. Ранние ксилографии подобно калькам иконописцев, выполнены линей но, что даёт основание предполагать, что подобные эскизы иконописцев могли использоваться $и$ художниками-графиками для создания гравюр. В любом случае, прототипами для создания ранних православных ксилографий служили либо непосредственно иконы, либо иконописные образцы для написания икон.

Упомянутые образы - прямые последовате ли византийских икон и миниатюр. По сути, это сербская гравюра, представляющая собой единое культурное явление с греческой графикой того периода. Авторы этих произведений черпали свое вдохновение, продолжая византийскую художественную традицию.

Нателла Алексеевна Топурия предполагает, что синайские листы печатались ещё ранее - в XV веке но не сохранились [13].

Представляет интерес одна из самых ранних известных нам синайских гравюр «Неопалимая Купи на, вид Монастыря св. Екатерины, Синай» мастер Корнилия. Исследователи её датируют 1665 г. [8] Эта композиция была очень популярна, так что с неё было сделано несколько свободно интерпретированных копий. Один такой уникальный лист конца XVII - начала XVIII в. хранится в собрании Музея Московской духовной академии (Papast. № 394) [7]. Гравюра интересна не только тем, что это одна из самых ранних известных нам греческих гравюр и самая древняя среди российских собраний, но и композиционным решением. Здесь представлен не только традиционный иконописный образ Неопалимой Купины, пророка Моисея и св. Екатерины, но интересным образом проиллюстрированная местность, художник создал повествовательный образ Святой Земли Монастыря Святой Екатерины. Всё иллюстрируе мое действо изображено на фоне аскетического горного пейзажа, а на переднем плане представлен небольшого размера монастырь. То есть эта икона репрезентует композицию, в которой важное значение начинает играть пейзаж.

Ещё одна ранняя синайская ксилография «Общий вид Синайского монастыря» выполнена мастером Акакием в 1665 г. [8, р. 341]. Композиция стилистически нарисована линией, а горный пейзаж представляет из себя подобие карты. Здесь использовано несколько приёмов пространственных построений одновременно: с одного ракурса воспринимаются зрителем двухмерно и условно изображённые плоские горы, а в другом ракурсе - земля Египетская. Здание монастыря изображено в аксонометрической проекции в виде сверху.

Следующие по времени гравюры с видом Синая были выполнены мастером Никодимом Зубрицким во Львове. Начиная с 1688 г. и до конца XVII в. им были созданы четыре похожие гравюры с незначительными отличиями (Papast. № 380383). Укажем на индексы и место хранения первых двух листов: Рараst. № 380 обрамлён декоративной рамочкой и хранится на Синае, Papast. № 381 находится в Национальной Библиотеке в Париже. Священные пейзажи здесь изображены с более глубоким пространством, здесь чётко видны передний и задний планы, по пространственным построениям эти листы ближе к видовой европейской гравюре. Мастер Никодим Зубрицкий активнее начинае использовать в гравюре фактуру и тоновое пятно, создавая моделировку форм в элементах пейзажа. Исследователи, занимающиеся творчеством Зубрицкого, имеют единое мнение о том, что все эти композиции были созданы по образцу гравюры Джованни Батиста Фонтана (1524-1587), созданной в Венеции в 1569 г. (ныне хранится в Галереи Уфицци) [15]. Её приводят как прототип Синайских видов исследователи Д. Папастрату [8, р. 338.] и В. Делюга [4, р. 383.]. В это же время был создан Моденский Триптих Эль Греко, на обороте которого мастер изобразил синайский пейзаж идентичной композиции. В конце XVI в. был создан ряд таких живописных композиций, триптихов, створки которых представляли синайский пейзаж. Известнь также работы Эль Греко «Синайский пейзаж» из Исторического музея на Крите, «Вид Горы Синай» из коллекции Ватикана неизвестного иконописца, створка триптиха из коллекции Бланта в Лондоне [15]. Поскольку все эти композиции были созданы примерно в одно время 1560-1590 гг., скорее всего, имелся некий источник, который послужил для них образцом. Возможно, это икона из собрания Монастыря Св. Екатерины, которую исследовательница Р. Тодорова приводит в одной из своих статей и датирует XIII в. [12]. А в XVII в. по этому иконографическому типу начали создавать синайски ксилографии, а потом и гравюры на меди с видом Синайского пейзажа.

Самая первая гравюра с видом Синая, которая предшествовала всем описанным выше, была создана в Париже по наброску французского натуралиста и профессора Пьера Белона (1517-1564), посетившего Турцию, Грецию, в том числе Афон, Палестину, Египет и Синайский полуостров, гравюра опубликована в иллюстрированном описании этого путешествия в 1553 г. [10]. Два пика Горь Синай здесь изображены единой каменистой массой с небольшим намёком на объёмность каменных блоков скал, а на переднем плане расположен крепостью монастырь Святой Екатерины. Из этого издания известно изображение также и Горы Афон, которое выполнено более детально и реалистично.

Описывать паломничества во Святую Землю и сопровождать такие описания путешествий иллюстрациями - древняя традиция. C XV в. культура паломничества становится популярнее, многие хотят некоторым образом зафиксировать воспоминания о пребывании на Святой Земле и поделиться впечатлениями с теми, кто ещё не соверши паломничество. Результатом экспедиции по святым местам декана Майнцского собора Бернгарда фон Брейденбаха стало издание «Путешествия в Святую Землю» в 1486 г., проиллюстрированное ксилографиями, созданными художником Эрхар дом Ройвихом - непосредственным участником этого путешествия. Художник изобразил землю Египетскую и скрытый в Синайских горах монастырь св. Екатерины [2]. Изображение представляет из себя более карту, чем пейзаж, наверняка не стояла задача добраться до Святой Земли по этой карте, но она красочно и условно передавала местоположение основных достопримечательностей относительно друг друга и натуралистично представляла их внешний вид. В это время, в 1493 была создана Нюрнбергская хроника учёным Хартманом Шеделем - книга с 1809 иллюстрациями среди которых «Вид Константинополя» композиционно очень похож на афонские гравюры с видами монастырей у берега моря [1].

Стоит отметить, что Синайский монастырь начинает первым издавать такие панорамные изображения с видом своей обители. Как известно, 
большинство гравюр заказывалось торговцем Хатзикириякисом у Никодима Зубрицкого и Дионисия Синкевича. Гравюры раздавались большими тиражами (до 1000 листов) паломникам. Часто монахи отдельных монастырей путешествовали по Европе и Российской Империи и раздавали гравюры с видами монастырей и святынь в обмен на пожертвования, что было особенно необходимо в период оккупации Османской Империей, возложившей на монастыри налоговую повинность.

Афонские монастыри по примеру «Богошественной Горы Синай», отметив пользу и эффективность раздачи таких гравюр при популяризации сведений о монастырях и для сбора средств на существование обителей, подхватили эту идею и начали активно заказывать в Европе, преимущественно в Венеции, гравюры с изображением монастыря и его святынь в сопровождении кратких описаний исторических и чудесных событий [3]. Нередко мастера, выполнявшие такие заказы, специализировались на производстве географи- ческих карт, которые в XVII-XVIII вв. изготовлялись в технике офорта и гравировки и отличались декоративностью и красотой исполнения. Как одну из ранних можно упомянуть гравированную карту Британских островов 1558 г. [11]. Они часто украшались рисунками кораблей и мифических рыб, которые можно встретить практически на всех графических видах афонских монастырей, начиная с синайских видов. Отчасти такие изображения копировались не только по эстетическим соображениям, но отображали опасную для монастырей историческую ситуацию - нападение на монастыри пиратов. Стремясь похитить материальные ценности на монастыри нападали турки, венецианцы, испанцы и пираты иного происхождения. Такие грабежи совершались начиная с XIII в., а с усилением турецкой власти - становились все более интенсивными [16]. Таким образом гравюры, иллюстрирующие сказочное пространство святых мест, часто были очень даже правдивыми в своём повествовании.

\section{БИБЛИОГРАФИЯ}

1. Ayse Yetiskin Kubilay Maps of İstanbul Haritaları 14221922 İstanbul: Denizler Kitabevi, 2010.

2. Breidenbach, Bernhard von. Peregrinatio in Terram Sanctam = Die heyligen reyssen gen Jherusalem. Mainz : Erhard Reuwich [cum typis Petri Schöfferi], 21.VI. 1486. Иллюстрация «Синая» Э. Ройвихом. - URL: https:// www.wdl.org/ru/item/18197/view/1/264/ (accessed 22.04.2021).

3. Della Dora V. Turning Holy mountains into ladders to heaven: overlapping topographies and poetics of space in poste-byzantine sacred engravings of mount Sinai and mount Athos // Approaching the Holy Mountain: art and liturgy at St Catherine's Monastery in the Sinai. -I. Series II. Gerstel, Sharon E. J. III. Nelson, Robert S., 1947. Pp. 505-535, p. 513.

4. Deluga $W$. Views of the Sinai from Leopolis. Shoter Notise. Print Quarterinq, XIV, 4. 1997. Р. 383.

5. Динко Д. Хиландарска графика. - Београд: «Просвета», 1990.

6. Kampanis M. The Printmaking Tradition on Mount Athos // The Orthodox Arts Journal. - URL: https:// orthodoxartsjournal.org/the-printmaking-tradition-onmount-athos/ (accessed 20.04.2021).

7. Краснова А. Гравюра «Неопалимая Купина. Вид Монастыря св. Екатерины, Синай»-уникальный памятник коллекции Музея МДА «ЦАК» // Богословский вестник. - № 2 (41). - 2021. p. 337-543.

8. Papastratos D. (1990). Paper Icons. Greek Orthodox Religious Engravings 1665-1899: (Vols. 1-2). Vol. 2. Athens. P. 360-361.
9. Petkovic S. Greek influence on illustrations in Serbian

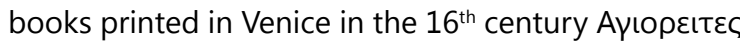

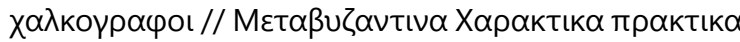

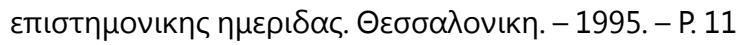

10. Пьер Белон. - URL: https://ru.wikipedia.org/wiki/Белон,_Ьер (дата обращения 22.04.2021).

11. Schüler C.J. Die Geschichte der Kartographie. Éditions place des victoires. Parise. 2010.

12. Todorova $R$. Icons as Maps: Cartographic icons in Orthodox art // Eikón Imago 7 - 2015. - № 1, p. 13-30.

13. Topuriya N. A., Hromov O. R. «Opisanie Ierusalima» Simeona Simonovicha i Hristofora Zhefarovicha $v$ russkih lubochnyih izdaniyah. Issledovaniyaya i svodnyiy katalog knig, hranyaschihsya v moskovskih sobraniyah. [«Description of Jerusalem» by Simeon Simonovich and Christopher Zhefarovich in Russian popular prints. Research and consolidated catalog of books stored in Moscow collections]. - M., 1996. - P. 110-120.

14. Vassilaki M. Working Drawings of icon painters after the fall of Constantinople. The Andreas Xyngopoulos portfolio at The Benaki Museum. - 2015. - № 75, 81.

15. Vassilaki M. Three Questions of the Modena Triptych URL: http://archive.eclass.uth.gr/eclass/modules/ document/file.php/SEAD216/M.\%20Vassilaki\%2C\%20 Three\%20Questions\%20on\%20 th $\mathrm{e} 20$ Modena\%20 Triptych.pdf (accessed 22.04.2021).

16. Зоитакис А. Энциклопедия Афона. Турецкое владычество. - URL: https://athos.guide/encyclopedia/ turetskoevladychestvo\#Святой_Афон_во_время_турецкого_владычества (accessed 22.04.2021). 